\section{Birlesik Dunya Arastrrma International Journal of BD-CENTER Learning and Teaching}

Innovasyon ve Yayıneılık Merkezi
Volume 13, Issue 3, (2021) 158-183

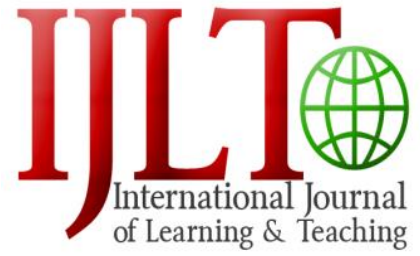

www.ij-lt.eu

\title{
The views of English teachers' towards school management and school managers*
}

\author{
Mehmet Guneyli ${ }^{{ }^{*},}$ Ministry of National Education and Culture, Nicosia, Turkish Republic of Northern Cyprus \\ Nazim Kasot ${ }^{b}$, Ministry of Tourism and Environment, Nicosia, Turkish Republic of Northern Cyprus / University \\ of Mediterranean Karpasia, Nicosia, Turkish Republic of Northern Cyprus
}

\section{Suggested Citation:}

Güneyli, M \& Kasot, N. (2021). The views of English teachers' towards school management and school managers. International Journal of Learning and Teaching. 13(3), 158-183. https://doi.org/10.18844/ijlt.v13i3.5971

Received from March 19, 2021; revised from May 15, 2021; accepted from July 22, 2021.

Selection and peer review under responsibility of Prof. Dr. Hafize Keser, Ankara University, Ankara, Turkey. ${ }^{\circ}$ 2021. Birlesik Dunya Yenilik Arastirma ve Yayincilik Merkezi, Lefkosa, Cyprus.

\section{Abstract}

In this research, it is aimed to evaluate the teaching of English in North Cyprus on the basis of educational administration. The scope of education management was determined according to the opinions concerning school management and school administrators. Qualitative research approach and case study model were used as basis in the research. Participants were selected in accordance with the purposeful sampling, maximum diversity and easily accessible case sampling. Accordingly, 23 English teachers from 6 districts working in secondary education of Norhern Cyprus Ministry of National Education were selected. The data were obtained through interviews and analyzed by content analysis. It is an important result of this research that school administrators have positive perspectives towards English teaching. It has been revealed that school administrators do not expect different tasks from English teachers when compared to other course teachers. It was noteworthy that the building of English language classrooms was one of the striking expectations of English teachers from school administrators.

Keywords: Foreign language education, English teaching, school management, school administrators, North Cyprus;

\footnotetext{
* AdDRESS FOR CORRESPONDENCE: Nazim Kasot, Ministry of Tourism and Environment, Nicosia, Turkish Republic of Northern Cyprus, University of Mediterranean Karpasia, Nicosia, TRNC.

E-mail address: nazimkasot@gmail.com / Tel.: +90-542-859-1499

This study is derivated from the first author's master thesis. Second author is the advisor of the thesis.
} 


\section{Introduction}

In this research, it is aimed to evaluate the foreign language education in the TRNC in terms of English education. English education was handled and evaluated in the administrative dimension and within the framework of teachers' opinions. Administrative dimension; How English teachers evaluate the management of the school they work, their views on the ideal school management, what kind of school administrator they want to work with, their positive and negative opinions about the school administrators they have worked with, the school administrators' approach to teaching English, the expectations from school administrators, The tasks given and the metaphors used for school administrators were discussed and evaluated.

It is thought that the findings obtained from this research will be important in terms of describing the situation of foreign language education in the TRNC. The number of studies in the literature on teaching English in the TRNC is limited; In this context, it is thought that the thesis will contribute to the literature. It can be said that the findings of this study will be valuable as a result of the thinking and self-evaluation of English teachers on subjects such as school management and school administrators. It can be said that the findings of the study can also be benefited from in higher education, as it will shed light on the current situation in English teaching in the country and reveal the existing shortcomings and positive aspects of the institutions that train English teachers at the higher education level in the TRNC. The findings of this study can guide the updating of the English curriculum in the TRNC.

\section{Conceptual Framework}

\subsection{Foreign language education}

Today, there are important advantages of having foreign language knowledge besides mother tongue. It is necessary to have a command of a foreign language or languages in order to follow scientific and technological developments in the world, to be informed about the existing news, to work in the field of business at an international level and to communicate with people from different cultures. People receive training to learn foreign languages in almost every period of their lives. These trainings have always been in a position that requires effort. From past to present, many different methods continue to be used to teach foreign languages. In addition to the methods used, the people who apply these methods and the place and time they are in are in a more important position. If the awareness of the foreign language teachers is increased, the awareness of the learners will also increase (Kumaravadivelu, 2003).

\subsection{School management}

School; It can also be considered as a system under the control of the state, where people who specialize in this field train students and provide them with knowledge and skills in order to achieve the planned educational goals (Ünal and Ada, 1999). Schools are institutions that bring positive behaviors to children and young people who are in the most effective position in moving society forward (Özdoğancl, 2019). Schools are organizations that organize and maintain educational activities within a certain plan, have a position and address a large area, and students, parents and teachers, who are important elements of schools, are constantly changing. Although this constant change sometimes causes difficulties, schools have to be successful in maintaining the balance. At this point, the school should adapt to the constantly changing situations, transform the behaviors of people to adapt to new conditions and even bring them new behaviors (Şengül, 2020).

School administrations have one of the biggest shares in fulfilling the goals of schools in the education process (Bursalıoglu, 2019). The school administrator, who is the basic element of the school 
administration, is the person who is in the position of influencing and motivating teachers to do their work. It is a necessary condition for the school administrator to act according to the law while conducting his business, but it may not be enough to do business with the law alone. In addition to legal authority, school administrators should also develop their own knowledge skills in order to determine how to behave according to different situations (Şişman \& Turan, 2005).

School administration is actually the educational administration on a smaller scale. Human and material resources are organized in a planned way in order to achieve the goal in school management. School administrators, on the other hand, can only be successful in fulfilling the authority and responsibilities on their shoulders if they work effectively (Şengül, 2020). If the school administrators eliminate the conflicts and problems within the institution and motivate the employees to do what the education requires, if they pay for the effort, if they increase the efficiency of the students by contributing to the educational situation, if they follow all technological developments closely and ensure that they are used in their own school, if they raise individuals who benefit the society when necessary, if they lead the people around and within the sphere of influence, then it can be said they are successful (Başaran, 1994).

\subsection{Opinions of foreign language teachers about school management}

English teachers can make some requests from school administrators related to their fields; Because, in order for the language course to be carried out appropriately, different environments, materials and tools may be needed compared to other courses. This situation can also cause economic burden. So what exactly are these teacher requests and how much are they taken into account by the administrators?

The first thing that English teachers often request from the school administration is to have a language laboratory. In such a laboratory environment, the ability of students to activate their senses of hearing, sight and touch when necessary will increase their interest in language learning and enable them to learn the language more effectively. The availability of different tools, equipment and materials other than the textbook is one of the main requests of English teachers. In addition, teachers want their administrators to have a driving force in learning English as a foreign language. The inadequacy of the physical structure, the weakness of the economic situation and the failure of the managers to show the desired attitudes can be shown as the reasons why the management did not respond adequately to these requests. Unless these situations are reversed, effective and efficient foreign language learning in schools is difficult (Mehdiyev,2019).

One of the factors that cause limitations and inadequacies in language learning is the repetitive application of almost the same techniques and methods, although it does not give positive results; that is, teaching grammar rules instead of communication skills and not using materials different from the textbook prevent the language from being learned adequately, that is, at a level that students can communicate. School administrators can also make some expansions in this regard. Within the framework of the opportunities they will provide for teachers, they can carry out activities that will enable students to communicate with individuals from different foreign groups, host students from different countries, and enable foreigners living around the school to come to school and communicate with students (Mehdiyev, 2019).

In addition to these, in order for foreign language learning to be more efficient, school administrators need to make lesson adjustments that will take into account four skills while arranging the lesson hours, and show an attitude in line with the wishes of the teachers when determining the classes or levels in which the English lesson will be given (Demir, 2016). 


\subsection{School management and foreign language education in TRNC}

The school administration is the unit that is authorized and responsible for the management of all kinds of education and training activities carried out within the body of a school, as well as for the administration of all other situations related to the school. When the schools in the TRNC are taken into consideration, the school principals and assistants constitute the structure that is accepted as the school administration.

The administrators who make up the school administration in the TRNC should be innovative, solve the problems, make appropriate decisions, and have verbal and written speaking skills. It is important that the school administration has a guiding role in the formation of all kinds of environments in the school. In addition, it is expected that the school administration should be democratic, have a strategy that motivates the school staff and students, and have a positive and creative vision in planning the future of the institution (Cyprus Turkish Education System, 2005).

School administrations in the TRNC should closely follow the technological developments, and in this context, they should adapt both themselves and the staff and students in their schools to the development in this direction. In our country, it is observed that school administrations that are in communication and cooperation with the people and institutions (such as municipality, district governorship) in the surrounding can receive significant contributions to their schools. Parents are as much a stakeholder in education as students. A school administration, which is in healthy communication with parents, takes positive steps in the educational and psychological development of students. In addition, a school administration that is in constant dialogue with top managers (such as the principals in the Ministry of Education) is also required (Cyprus Turkish Education System, 2005).

Foreign language; It can be said that it is a language that is not generally spoken in the place where a person lives and that contributes to the communication of people from other nations and cultures. The first foundation of knowing and learning a foreign language can be laid in primary and secondary education and its development can be carried out in these periods. If we look at the foreign language education in the TRNC, we can state that the most widely taught foreign language is English. English education is given in schools from the first years of primary education until the 12th grade, which is the last level of secondary education, and it is aimed that a student who has completed the 12th grade will know English at B2 level according to the European criteria. In the TRNC education system, German, French or Greek languages are also taught in secondary education. In this context, it is aimed that a student who has completed the 12th grade will know German and French at B1 level according to the European criteria (Cyprus Turkish Education System, 2005).

When we look at the framework for foreign language education in the TRNC, it is seen that it is based on the "Common European Framework for Language Learning and Teaching" . The aim of the language program in the country is to increase the level of mutual communication of the students, which can be achieved mostly by addressing the language used in real life. In this context, the language teacher should design the lesson according to real social environments, determine the materials to be used towards this goal and support them with the technological infrastructure. While students are expected to be interactive and communicate more with each other, the mistakes they will make should be accepted as a part of the natural process and should be corrected with methods that will not interrupt communication (Cyprus Turkish Education System, 2005). On the other hand, while the debate continues on how much this targeted language program has been achieved, when we look at the current language education in the TRNC, it is seen that these targets have not been achieved. In particular, the fact that even the English language is not learned enough to enable 
communication remains a problem, despite the highest number of lessons and it has been in the education system for many years.

In the Language Education Commission held in the National Education Council held in 2014, the framework of the existing problems was drawn while presenting suggestions on foreign language education. In this context; the existence of crowded classrooms, the insufficient technological equipment of the classrooms, the lack of necessary materials and resources, the inadequacy of some of the teachers who teach English at the primary school level, the lack of teaching English for the profession and the field in vocational technical schools, and the teaching to memorize the traditional grammar rules more in foreign language teaching have been revealed as important problems in foreign language education. A foreign language education that emphasizes the problems related to foreign language education and that it cannot be done at the desired level and that these are corrected and that communication skills will be brought to the fore and important were also discussed in the Institutional and Functional Education of the TRNC Ministry of National Education and Culture prepared by the Economic Policy Research Foundation of Turkey (TEPAV) Analysis report (2012) and in Vision 2030 Education Strategic Plan Workshop Report (2019) conducted by TRNC Ministry of National Education and Culture.

\section{Methodology}

\subsection{Model}

The research was based on a qualitative approach and a case study model was used. According to Yıldırım and Şimşek (2021), a case study is a description of the situation to be researched by obtaining in-depth, holistic and comprehensive data. The situation examined in this research is the situation of foreign language education in the TRNC education system. The reason for choosing English language education is that the researcher works in this branch.

\subsection{Participants}

In the research, in accordance with purposive sampling, maximum diversity and easily accessible situation sampling were taken as basis and participants were determined. The rationale for using maximum diversity is related to the inclusion of English teachers with different characteristics according to socio-demographic variables such as seniority, gender, and region of work. The easily accessible case sampling was used in order to reach the English teachers who are around the researcher in a short time, with a fast and economical understanding, and who he thinks will obtain rich data. Accordingly, 23 English teachers were included in the study. Table 1 presents the characteristics of the participants. 
Table 1. Socio-demographic characteristics of English teachers participating in the study

\begin{tabular}{|c|c|c|}
\hline & $\mathrm{n}$ & $\%$ \\
\hline \multicolumn{3}{|l|}{ Gender } \\
\hline Female & 20 & 87 \\
\hline Male & 3 & 13 \\
\hline \multicolumn{3}{|l|}{ Age } \\
\hline 30 years and under & 6 & 26 \\
\hline $31-40$ years & 7 & 30 \\
\hline $41-50$ years & 7 & 30 \\
\hline 51 years and older & 3 & 13 \\
\hline \multicolumn{3}{|l|}{ Seniority } \\
\hline $0-5$ years & 8 & 35 \\
\hline $11-20$ years & 8 & 35 \\
\hline 21 years and above & 7 & 30 \\
\hline \multicolumn{3}{|l|}{ Location of Graduated University } \\
\hline TRNC & 14 & 60 \\
\hline Turkey & 5 & 22 \\
\hline Other & 4 & 17 \\
\hline \multicolumn{3}{|l|}{ Educational Status } \\
\hline Undergraduate & 13 & 57 \\
\hline Graduate & 10 & 43 \\
\hline \multicolumn{3}{|l|}{ District of the School Served } \\
\hline Nicosia & 3 & 13 \\
\hline Famagusta & 5 & 22 \\
\hline Kyrenia & 5 & 22 \\
\hline Güzelyurt-Lefke & 2 & 9 \\
\hline İskele & 8 & 35 \\
\hline \multicolumn{3}{|l|}{ Type of the School Served } \\
\hline High School and Secondary School & 10 & 43 \\
\hline Collage & 12 & 52 \\
\hline Vocational & 1 & 4 \\
\hline Art & - & 0 \\
\hline Science & - & 0 \\
\hline Anadolu Lycee & - & 0 \\
\hline
\end{tabular}

\subsection{Data collection tool and process}

In this study, a semi-structured interview form developed by the researcher was used. While preparing the interview form, the literature was used, the opinions of the field experts were consulted and a pilot application was made. Care was taken to ensure that the questions in the opinion form were clear and understandable and consistent with the research purpose.

In the research, the following questions were written about the views of English teachers about school management and administrators : 
1. How would you evaluate the management in your school in general, and could you indicate your positive and negative thoughts? What do you think the ideal school management should be like?

2. What kind of school administrator would you like to work with?

3. What are the positive behaviors that you like and remember in the school administrators you have worked with until today?

4. What kind of behaviors have you encountered in the school administrators that you have worked with so far that you do not like or that you would describe as negative?

5. How would you evaluate your school administrators' perspectives or approaches to teaching English?

6. What are the expectations of your school administrators from you as an English teacher? What kind of tasks do they give you, unlike other teachers?

7. As an English teacher, what would be the first three things you would ask your school administrator to do? Can you give an example?

8. As an English teacher, if you had to compare your school administrator to anything animate or inanimate, what would you compare it to? Answer by completing the sentence below.

My school administrator is like ; because

Before applying the interview form, application permission and ethical evaluation decision were obtained from the TRNC Ministry of National Education and Culture. Interviews were held in the Fall semester of the 2020-2021 academic year. The interviews were generally held in schools, and from time to time on the internet due to the pandemic. The interviews lasted between half an hour and an hour. Depending on the consent of the participants, data were collected in the form of audio recording, visual recording, taking notes by the researcher, and taking written opinions. It has been stated that no names will be used in the data collection process in accordance with ethical rules, opinions will be kept confidential and used only for scientific purposes and in the thesis, opinions will not be used without the consent of the interviewee, they can be abandoned during the interview process if desired, and volunteerism will be taken into consideration.

\subsection{Data analysis}

The opinions obtained in this study were evaluated and interpreted with content analysis. In the research, each question in the interview form was accepted as a category. Key words, in other words, codes were determined in the opinions of the English teachers who gave their opinions under these categories. Similar codes were grouped together and classified. Each class or group is given a theme name. While presenting the themes, tables were used and presented in a way that the reader could best understand. For the reliability of the data analysis, the consistency of the coding was checked. The consistency between the two researchers was $80 \%$ and it was concluded that the analysis was reliable.

\section{Findings}

In the findings section, the opinions of English teachers about school management are presented as a result of the content analysis. 
Table 2. positive opinions of english teachers about school management

\begin{tabular}{|c|c|c|}
\hline Main Theme & Sub Themes & $\mathbf{N}$ \\
\hline & Just and equitable & 15 \\
\hline & Disciplined & \\
\hline & Be kind and understanding & \\
\hline \multirow{8}{*}{$\begin{array}{l}\text { The personality traits of the school } \\
\text { administrator affect the school } \\
\text { administration positively. }\end{array}$} & Honest & \\
\hline & Trustworthy & \\
\hline & Carefully & \\
\hline & Problem solver & \\
\hline & Based on functionality & \\
\hline & Not rule oriented & \\
\hline & Consistent & \\
\hline & Pleased & 9 \\
\hline \multirow{3}{*}{$\begin{array}{l}\text { Satisfaction with school } \\
\text { administration }\end{array}$} & Effective & \\
\hline & Positive & \\
\hline & Good & \\
\hline \multirow{3}{*}{$\begin{array}{l}\text { School management is carried out } \\
\text { taking into account the teacher. }\end{array}$} & Collaborating with the teacher & 4 \\
\hline & Supervising the teacher & \\
\hline & Appropriate distribution of tasks & \\
\hline \multirow[t]{3}{*}{$\begin{array}{l}\text { School management is carried out } \\
\text { taking into account the student. }\end{array}$} & $\begin{array}{l}\text { Providing students with a comfortable school } \\
\text { environment }\end{array}$ & 3 \\
\hline & Following the student's performance & \\
\hline & $\begin{array}{l}\text { Able to manage the school according to different } \\
\text { student profiles }\end{array}$ & \\
\hline
\end{tabular}

According to Table 2, the positive opinions of the English teachers participating in the research on school management are grouped under 4 main themes. These themes are; "The personality traits of my school administrator positively affect the school administration", "I am satisfied with the school administration", "School administration is carried out taking into account the teacher" and "School administration is carried out taking into account the student". The main theme "Personality characteristics of my school administrator positively affect the school administration" was expressed as a total of 15 opinions and consisted of the following sub-themes: being fair and egalitarian, disciplined, well-intentioned and understanding, honest, reliable, careful, problem-solving, functionality-based, rule-based. unfocused and consistent. The opinions of 3 English teachers regarding these sub-themes are presented below:

"In my opinion, an ideal school administration is related to the fact that the principal is fair, honest and reliable." (T4)

"Our school management is following an egalitarian, problem-solving and practical approach this year." (S11)

"I think it's a good form of management in general. The duties of teachers and administrators are carried out within the framework of necessary discipline and mutual understanding." (T19)

The main theme of "I am satisfied with the school administration" was expressed as a total of 9 opinions and was explained with definitions such as satisfied, effective, positive and good without giving too much detail. The opinions of 3 English teachers regarding these sub-themes are presented below:

"I am satisfied with our school administration." (T3)

"I find the school administration very effective." (T5)

"The general approach of our administration to the events is positive." (S7) 
"School management is carried out taking the teacher into account, and its main theme is expressed as a total of 4 views. Under this main theme; School administrators who cooperate with the teacher, supervise the teacher and distribute the tasks appropriately to the teachers were found to be successful and effective. The opinions of 2 English teachers regarding these sub-themes are presented below:

"However, if we look at the management style at my school, yes, the principal is trying to ensure that students receive education in the most efficient and effective way and keeps teachers under close watch." (T4)

"Teachers' duties have been duly determined and maintained within the framework of necessary discipline and mutual understanding." (T19)

The last main theme related to this question was defined as "actualizing school management by taking into account the student". This sub-theme was presented as 3 views; The aforementioned sub-themes were determined as providing a comfortable school environment to the students, monitoring the student's efficiency and managing the school according to different student profiles. The opinions of 2 English teachers regarding these sub-themes are presented below:

"A disciplined but comfortable environment was created for teachers and students" (T1)

"During my time as a teacher, the school administration can vary according to the student profile. This is a positive and good thing for me..." (T17)

Table 3. Negative Opinions of English Teachers about School Management

\begin{tabular}{|c|c|c|}
\hline Main theme & Sub Themes & $\mathbf{N}$ \\
\hline $\begin{array}{l}\text { Problems related to the school } \\
\text { administrator's management skills }\end{array}$ & $\begin{array}{l}\text { The principal's dictatorial management of the } \\
\text { school } \\
\text { Making last-minute decisions } \\
\text { not taking initiative } \\
\text { Don't give too much tolerance to the student } \\
\text { The school administrator's use of politics in the } \\
\text { administration }\end{array}$ & 5 \\
\hline & Not accepting teachers' opinions & 3 \\
\hline $\begin{array}{l}\text { School administrator's conflict } \\
\text { with teachers }\end{array}$ & $\begin{array}{l}\text { Not getting along with teachers } \\
\text { Not accepting teachers }\end{array}$ & \\
\hline Inadequate school administration & $\begin{array}{l}\text { Bad } \\
\text { Insufficient }\end{array}$ & 3 \\
\hline $\begin{array}{l}\text { Negative impact of out-of-school } \\
\text { stakeholders on school } \\
\text { management }\end{array}$ & $\begin{array}{l}\text { The negative impact of the Ministry of Education } \\
\text { on school management } \\
\text { Negative effect of school-parent union on school } \\
\text { management (pressure) }\end{array}$ & 2 \\
\hline
\end{tabular}

According to Table 3, the negative opinions of the English teachers participating in the research on school management are grouped under 4 main themes. These themes are; "Problems related to the management skills of the school administrator", "The conflict of the school administrator with the teachers", "The inadequacy of the school administration", "The negative impact of the non-school stakeholders on the school administration". The main theme of "problems related to the management skills of the school administrator" was expressed as a total of 5 views and consisted of the following sub-themes: the principal's dictatorial management of the school, the lastminute decision making, not taking initiative, giving too much tolerance to the student, the school 
administrator's use of politics in the administration. The opinions of 2 English teachers regarding these sub-themes are presented below:

"The administration at our school is very bad. School administration should be in a democratic structure. The fact that the director is a dictator makes the environment completely negative." (T2)

"Unfortunately, our principals and assistants are generally actively involved in politics and I think their political views affect their approach to teachers." (T12)

The main theme of "the school administrator's conflict with the teachers" was expressed as 3 views and consisted of the following sub-themes: not accepting the teachers' opinions, not reconciling with the teachers, not accepting the teachers. The opinion of 1 English teacher regarding these sub-themes is presented below:

"The principal is trying to ensure that students receive education in the most efficient and effective way and keeps teachers under close follow-up. But he does not accept the views of teachers on certain issues and does not try to find a common way." (T4)

The main theme of "inadequate school administration" was expressed as 3 views and consisted of the following sub-themes: bad, insufficient. The opinion of 1 English teacher regarding these sub-themes is presented below:

"The school administration generally tries to do its best, but it is insufficient from time to time. (especially taking initiative)" (T16)

Finally, the main theme of "Out of school stakeholders negatively affect the school administration" was expressed as 2 views and consisted of the following sub-themes: The negative impact of the Ministry of Education on the school administration, the negative impact of the school-parent union on the school administration (pressure). The opinion of 1 English teacher regarding these sub-themes is presented below:

"This year's school administration (during the pandemic) couldn't have been better. They handle everything wonderfully. In this process, I think it is the Ministry of Education that puts us and the school administration the hardest." (S9)

Table 4. Views of English Teachers on Ideal School Management

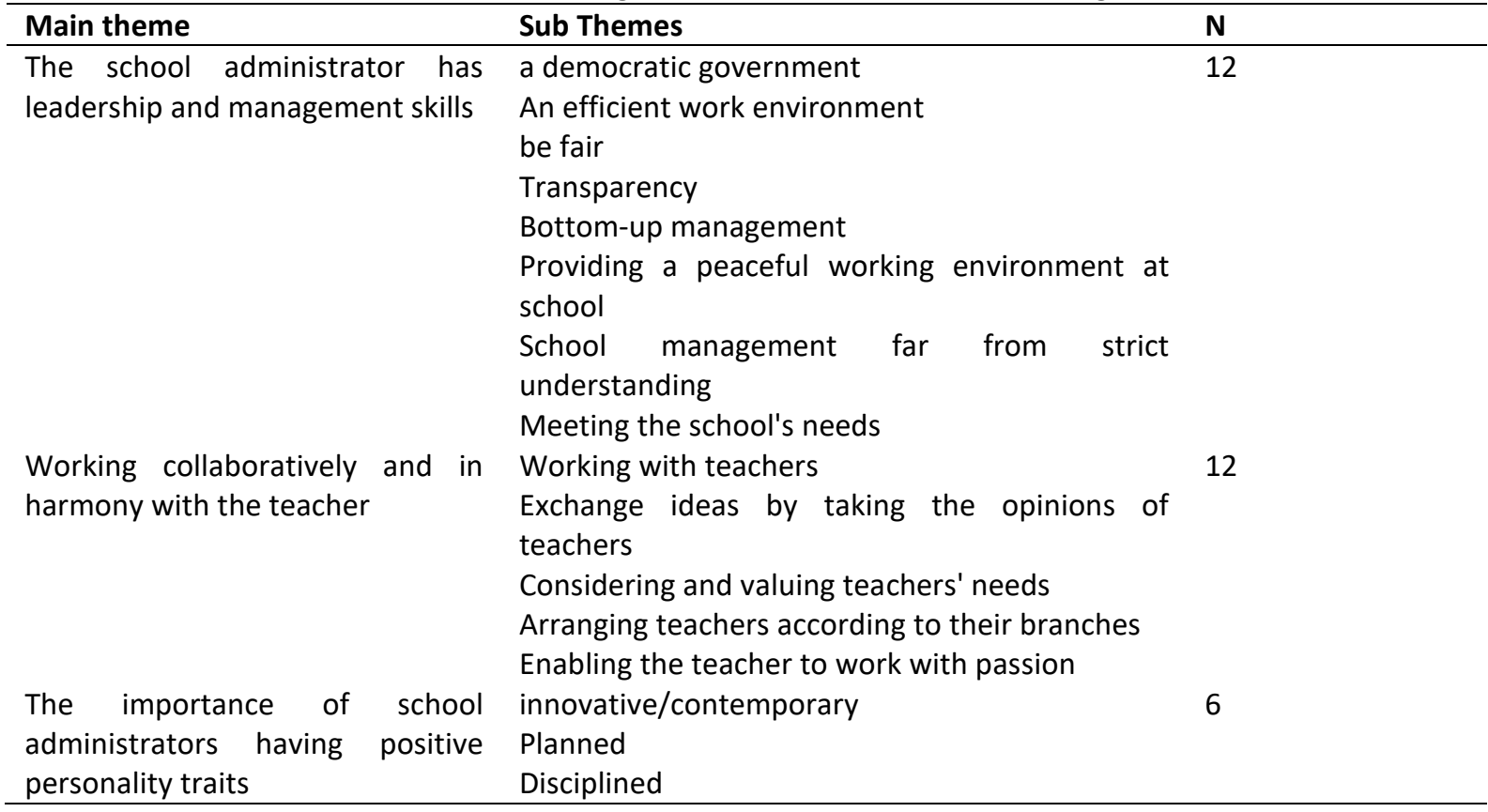


Managing the school based on student progress

Ability to work collaboratively with out-of-school stakeholders

Being indecisive about ideal no idea school management
Creating the ideal learning environment for 6 students

Working with students

Preparing students for life

Considering students' needs

Balancing internal and external factors

1

1

According to Table 4, it is seen that English teachers have a total of 38 opinions regarding ideal school management. 12 of these views are related to the main theme of "School administrators have leadership and management skills". The sub-themes in this main theme are as follows: democratic management, an efficient working environment, fairness, transparency, top-down management, providing a peaceful working environment at school, school management far from rigid understanding, meeting the needs of the school. The opinions of 3 teachers on these sub-themes are as follows:

"A management that allows every group (teacher, student...) in the school to have a say" (T15)

"I don't know if there is such a thing as an ideal school management, but ideally, disciplined and planned work and programming, fair distribution of tasks among teachers and its consistency, transparency in practices and school management that can always be bottom-up rather than topdown are among the essentials. There should be a building on hierarchical balance." (T12)

"He tries to meet the deficiencies and needs of the school, regardless of material or moral. It keeps the school and work environment peaceful." (T18)

The 5 sub-themes related to the main theme of "working in cooperation and harmony with the teacher" were revealed as follows: acting together with the teachers, exchanging ideas by taking the opinions of the teachers, taking into account the needs of the teachers and valuing them, arranging according to the branches of the teachers, the teacher's willingness to work providing. The opinions of 3 teachers on these sub-themes are as follows:

"The ideal school administration should be in an environment that acts with their teachers." (T1)

"The ideal school administration should provide an efficient working environment, taking into account the goals and needs of teachers." (T6)

"Continuous exchange of ideas with teachers" (T14)

For another main theme, "The importance of having positive personality traits of the school administrator", 3 sub-themes were put forward: innovative/contemporary, planned, disciplined. The opinions of 2 teachers regarding these are as follows:

"The ideal is one that respects different ideas and is innovative." (S11)

"The ideal school administration should be open to other ideas within the framework of logic, valuing its teacher, authoritative, and aiming at modern education by constantly following innovations" (T16)

"Managing the school based on the development of the student" is another main theme and includes 3 sub-themes. The total number of views is 6 . Sub-themes related to the main theme mentioned are as follows: creating an ideal learning environment for students, acting together with students, preparing students for life, taking into account the needs of students. The opinions of 2 teachers regarding these are as follows:

"A management that gives importance not only to the academic success of its students but also to their preparation for life." (T15)

"The ideal administration acts by prioritizing the needs of its students." (T18) 
The fifth main theme for ideal school management is "Working in cooperation with out-of-school stakeholders". There is only one sub-theme related to the main theme in question. This sub-theme was determined as "Balancing the factors inside and outside the school". 1 teacher's opinion on this is as follows:

"The administration, school, which we have the appointment and staff of the Ministry of National Education should establish a good balance of internal and external factors." (T12)

"Being indecisive about ideal school management" was put forward as the last main theme for ideal school management, and there is 1 sub-theme related to this. This sub-theme was determined as "No idea".

"I am undecided about the ideal school administration. I was never enthusiastic about school management because I was indecisive." (T3)

Table 5. Opinions of english teachers on what kind of school principal they want to work with

\begin{tabular}{ll}
\hline Theme & N \\
\hline Empathetic, listening, sensitive and understanding & 14 \\
Objective, fair and equitable & 12 \\
Recognizing teachers, knowing their needs, respecting and valuing them & 10 \\
Leadership and management skills & 10 \\
Disciplined, principled, hardworking and consistent & 9 \\
Following the developments in education, self-renewing and idealist & 8 \\
Motivating and enabling the development of teachers and students & 7 \\
Solution oriented & 7 \\
Effective communicator and good interpersonal & 7 \\
\hline
\end{tabular}

According to Table 5, 84 opinions were presented under 9 different themes regarding what kind of school administrators English teachers would like to work with. The 9 themes mentioned are as follows: "empathic, listening, sensitive and understanding", "objective, fair and egalitarian", "knowing teachers, knowing their needs, respecting and valuing them", "having managerial skills and being a leader", " disciplined, principled, hardworking and consistent", "following the developments in education, self-renewing and idealistic", "enabling and motivating the development of teachers and students", "solution-oriented", "effective communication and good human relations".

There are 14 teachers' views on the theme of "empathic, listening, sensitive and understanding", and 3 teachers' views on this theme are as follows:

"Able to empathize with teachers, think from both student and teacher side, ask more than command, and communicate well." (T1)

"Disciplined, respectful, sensitive and forward-looking" (S7)

"Fair, empathetic, foresighted" (T10)

12 views were determined for another theme, "Objective, fair and egalitarian". The opinions of 3 teachers about this are as follows:

"I read something that administrators who are fair and have good communication skills show better management in schools." (T3)

"With a manager who is objective, equidistant from all his teachers, can take initiative when necessary and is solution-oriented" (T5)

"Adil, taking into account the problems and needs of teachers, self-development in the field of education, providing opportunities for teachers to improve themselves" (T6)

There are 10 views on the theme of "knowing teachers, knowing their needs, respecting and valuing them", and 3 teacher views on the theme are given below: 
"There should be a principal who respects, listens and evaluates the ideas and opinions of teachers and then expresses his opinion." ( S4)

"With a manager who takes into account the needs of teachers" (T13)

"Valuing their teacher, self-developing, respectful to students and teachers, pedagogically developed, able to empathize, directing the teacher" (T16)

You can find the opinions of 3 teachers below among the 10 opinions determined for the theme "Having management skills and a leader":

"There must be a person with human values and managerial skills" (T8)

"First of all, I would like to work with a fair, good manager and solution-oriented manager." (S9)

"Disciplined, leader, problem solving and understanding in practice" (T19)

There are 9 opinions for another theme, "disciplined, principled, hardworking and consistent". We can list the three teacher opinions for this theme as follows:

"It should be principled, egalitarian, hardworking, motivating." (S11)

"I would like to work with a manager who is successful in human relations, has high social intelligence, has the qualities of a leader, not a boss, is accessible, fair, but hard and consistent where necessary, and disciplined." (T12)

"Disciplined, leader, problem solving and understanding in practice" (T19)

The opinions of 3 teachers out of 8 for the theme of "following the developments in education, selfrenewing and idealistic", which is among the themes about what kind of school administrators English teachers would like to work with, were presented as follows:

"There should be a principal who follows the developments in the country and the world related to education, renews himself constantly, respects, listens and evaluates the ideas and opinions of teachers and teachers, and then expresses his opinion. " (S4)

"Fair, taking into account the problems and needs of teachers, self-development in the field of education, providing opportunities for teachers to improve themselves" (T6)

"A school administrator who is disciplined, fair, understanding, listening, giving justice to his position and open to continuous improvement..." (T15)

7 views were determined for the theme of "enabling and motivating the development of teachers and students" and 3 teachers' views on this subject are given below:

"It should be principled, egalitarian, hardworking, motivating." (S11)

"With a manager who takes into account the needs of teachers and students" (T13)

"Valuing their teacher, self-developing, respectful to students and teachers, pedagogically developed, able to empathize, directing the teacher" (T16)

Among the determined themes, the opinions of 3 teachers among the 7 opinions expressed for "Solution-oriented" are as follows:

"With a manager who is objective, equidistant from all his teachers, can take initiative when necessary and is solution-oriented" (T5)

"Listens to the teacher and helps in solving problems" (T14)

"Disciplined, leader, problem solving and understanding in practice" (T19)

7 opinions were expressed for the last theme, "who communicates effectively and has good human relations", which is among the themes about what kind of school administrator English teachers want to work with. The opinions of 3 teachers on this subject are presented as follows.

"I read something that administrators who are fair and have good communication skills show better management in schools." (T3)

"The teacher should have the ability to communicate well with students, other staff and parents. (T4) 
"I would like to work with a manager who is successful in human relations, has high social intelligence, has the qualities of a leader, not a boss, is accessible, fair, but hard and consistent where necessary, and disciplined." (T12)

Table 6. Characteristics english teachers like in school administrators they work with

\begin{tabular}{ll}
\hline Theme & N \\
\hline He is good at human relations and communicates effectively. & 11 \\
Empathizes, understanding and positive. & 9 \\
It is fair, honest and egalitarian. & 7 \\
Recognizes, supports and motivates the teacher. & 7 \\
He is knowledgeable, hardworking and disciplined. & 4 \\
Recognizes and guides students and gives importance to their development. & 4 \\
It is planned, makes effective decisions and can perform different tasks. & 4 \\
He is visionary, innovative and visionary . & 3 \\
It provides the needs of the school and creates a productive environment. & 2 \\
He is cooperative and helpful. & 2 \\
Supervises and evaluates. & 1 \\
It takes into account the school-family bond. & 1 \\
\hline
\end{tabular}

55 views emerged under 12 themes regarding the "Facts That English Teachers Like About the School Administrators They Work With". The identified themes are: "good in human relations and communicate effectively", "empathic, understanding and positive", "fair, honest and egalitarian" "recognizes, supports and motivates the teacher", "informed, hardworking and disciplined." , "knows and guides students and gives importance to their development", "plans, makes effective decisions and can fulfill different tasks", "is predictive, innovative and visionary", "provides the needs of the school and creates a productive environment", "cooperates and helpful", "supervises and evaluates", "takes into account the school-family bond".

Considering the opinions expressed on the themes, 11 opinions on the theme "He is good in human relations and communicates effectively" emerged, and the opinions of 3 teachers are as follows:

"To be fair, to conduct relations within the framework of human values, to have empathy..." (T3)

"The fact that administrators communicate well with teachers..." (S6)

"When there is a problem, go to your teachers and pay close attention." (T21)

9 views were put forward for the theme of "He empathizes, is understanding and positive" and 3 teachers' views on this were as follows:

"He empathizes with teachers." (T4)

"One of my favorite features is the manager who can empathize and has the knowledge and vision by giving direction." (T5)

"Yes, I have seen very positive school administrators. He always respected our opinions. He was always positive and always smiling."

7 opinions were determined for another theme, "it is fair, honest and egalitarian". The opinions of 2 teachers about this theme are as follows:

"Those who have a developed human aspect, who have a high sense of justice and who stand behind the teacher, who can multitask are the ones that stay in my mind." (S9)

"I like that they are innovative, egalitarian, hardworking and motivating." (S11) 
7 views on the theme "Recognizes, supports and motivates the teacher" were presented and 2 teacher views on this theme were expressed as follows:

"The school principal's helping me develop in my own field, offering ideas and providing motivation..." (S16)

"It is very important for him to value and support his teacher" (T18)

"Knowledgeable, hardworking and disciplined." There are 4 opinions under the theme. One teacher's opinion on this theme is as follows:

"The understanding of our current school principal is good. When I worked in Bekirpaşa, the discipline and foresight of the manager was good." (T17)

Regarding the theme of "knowing and guiding students and giving importance to their development", which was put forward for the positive behaviors of school administrators, 4 opinions were determined and 1 teacher's opinion on this theme is given below:

"Approaching children with love, guiding them, being a manager who does not impose harsh punishments, taking care of the deficiencies of the school and trying to make up for it..." (T20)

The following is the excerpt from 1 teacher's view out of 4 opinions on the theme "It has a plan, makes effective decisions and can fulfill different tasks":

"I had the chance to work with only one principal, who could prepare programs in which my duties were determined in advance rather than at the last minute, who could speak strongly and well, who valued his teacher's opinion and tried to get to know his teachers personally, who could distinguish between hardworking and non-working ones, and treated everyone as they deserved, That's why I always keep him separate." (T12)

Three opinions were put forward for the theme of "presponsive, innovative and visionary", which is among the 12 themes determined. One teacher's view on this theme is as follows:

"One of my favorite features is that he is a manager who can empathize, is open to innovations and has knowledge and vision by directing..." (T5)

There are 2 views on the theme of "It provides the needs of the school and creates a productive environment" and 1 teacher's opinion is as follows:

"The school's efforts to deal with its deficiencies..." (T20)

Among the emerging themes, there are 2 views on the one "cooperates and is helpful". 1 teacher's opinion on this theme is as follows:

"Our school principal is constructive and helpful." (T10)

The last two themes, for each of which an opinion was put forward, are "supervision and evaluation" and "takes into account the school-family bond". Teachers' views on these themes are as follows, respectively:

"The principal and assistants visit the classrooms from time to time and make observations and inspections..." (S7)

"Communicating with the parents ..." (S4) 
Table 7. Characteristics that english teachers do not like in school administrators they work with

\begin{tabular}{ll}
\hline Theme & N \\
\hline Does not listen, does not exchange ideas and human relations are weak. & 9 \\
Does not try to get to know the teacher, does not understand and conflicts. & 8 \\
They are rude and unsympathetic, show no respect and lack empathy. & 7 \\
Has negative personality traits (hypocrisy, jealousy, high ego, low self-esteem, & 7 \\
prejudiced, scary). & 4 \\
It discriminates and favors. & 4 \\
No problem solving skills. & 4 \\
It is strict and task oriented. & 4 \\
It does not meet the needs of the school and does not provide efficiency. & 3 \\
He does cursory work and is undisciplined. & 2 \\
There is no managerial qualification. & 2 \\
Doesn't understand student psychology. &
\end{tabular}

12 themes related to the characteristics that English teachers did not like in school administrators they work with were identified and 55 opinions were put forward. The themes were determined as follows: "rude and unsympathetic, does not show respect and empathy", "discriminates and favors", "does not listen, does not exchange ideas and human relations are weak", "no problem solving skills", "does not try to get to know the teacher, does not understand and conflicts", "strict and task-oriented", "has no managerial qualities", "does not meet the needs of the school and does not provide efficiency", "does cursory work and is undisciplined", "negative personality traits (hypocrisy, jealousy, high ego, lack of self-confidence, prejudiced, frightening)", "no negative behavior", "does not understand student psychology"

Within the scope of this question, 3 teachers' views on the theme of "does not listen, does not exchange ideas and human relations are weak", which is most frequently mentioned with 9 views, are as follows.

"Behaving distantly and not listening, being unfair, lacking empathy..."( T3)

"Duty-oriented, immature, egoistic, jealous, uncivilized behaviors that have nothing to do with management (Managers who are incapable of even saying get well after a serious illness)" (S9)

"Not interfering with the deterioration of the relations between the administrator and teachers, not presenting his opinion, obeying only the written rules, not prioritizing the needs of the school..." (T18)

Out of 8 opinions on the theme of "Does not try to get to know the teacher, does not understand and conflicts", 3 teacher opinions are given below:

"Those who keep all the rules above everything else and do not act solution-oriented when necessary and cannot bend because of the rules..." ( S5 )

"Not giving importance to the ideas and decisions of the teacher, limiting the autonomy of the teacher" (T16)

"Lack of ability to listen, and in some cases, limited understanding of branch issues..." (T10)

7 views were expressed on the theme of "rude and unsympathetic, does not show respect and does not empathize". The opinions of 2 teachers on this theme are given as follows:

"They were rude, unsympathetic, and devoid of student-teacher psychology." (T1)

"I didn't like that they felt like a sultan. They were people who never listened to the opinions of the other person and did not respect the person in front of them at all." (T2) 
On the other hand, 7 opinions were emphasized for "having negative personality traits (hypocrisy, jealousy, high ego, low self-confidence, prejudiced, scary)", which was put forward as another theme, and the following 2 teacher opinions were presented:

"There were times when we observed that there were hypocrisy and superficial deeds" (T8)

"An administration that gossips about everybody, goes behind their backs and denies it..." (T22)

While a total of 4 views were focused on the theme of "It discriminates and favors", 1 teacher's opinion was as follows:

"An administration that does not treat its teachers fairly and unequally and that gives personal privileges..." (T13)

4 opinions were determined within the framework of the theme determined as "no problem solving skills". 1 teacher's opinion on this theme is given below:

"Behaviors where inconsistent decisions are made in case of any problem, in a state of panic and without thinking in detail..." (T19)

There are 4 opinions under the theme of "It is strictly prescriptive and task-oriented". One of these views is:

"Principals who do not have self-confidence and who try to compensate for this by showing strength and "command" are also very negative examples..." (T12)

Another theme for the question is "does not meet the needs of the school and does not provide efficiency". There were 4 opinions regarding this theme and 1 teacher's opinion among them is given below:

"Doesn't interfere with the deterioration of the relations between the administrators and teachers, only obeys the written rules, does not prioritize the needs of the school..." (T18)

Among the themes, 1 teacher's opinion on the theme of "does cursory work and is undisciplined", which is included with 3 views, is presented as follows:

"He was incompetent, distant from students and teachers, undisciplined and prejudiced, applying double standards." (T15)

There were 2 opinions regarding the theme "There is no managerial qualification", 1 of which is given below:

"Duty-oriented, immature, egoistic, jealous, uncivilized behaviors that have nothing to do with management (Managers who are incapable of even saying get well after a serious illness)" (S9)

Two opinions were expressed for another theme, "the student does not understand psychology". One teacher's opinion on this is as follows:

"They were rude, unsympathetic, and devoid of student-teacher psychology." (T1)

The last theme related to this question, "no negative behavior", was put forward with 1 opinion. The said opinion is given as follows:

"I did not observe any negatives." (T23) 
Table 8. Perspectives and approaches of school administrators towards teaching english

\begin{tabular}{|c|c|c|c|}
\hline Main theme & Sub Themes & $\mathbf{N}$ & $\begin{array}{l}\mathbf{N} \\
\text { Total }\end{array}$ \\
\hline & It has a positive effect. & 7 & \\
\hline & He cares and believes in its necessity. & 7 & \\
\hline & It supports effective English teaching. & 4 & \\
\hline & It provides material supply. & 4 & \\
\hline Positive Outlook & $\begin{array}{l}\text { It communicates with the Ministry of Education and } \\
\text { provides the necessary learning environment. }\end{array}$ & 2 & 25 \\
\hline & It won't cause any problems. & 1 & \\
\hline & It doesn't matter. & 2 & \\
\hline & $\begin{array}{l}\text { Does not understand English teaching and does not } \\
\text { empathize with teachers. }\end{array}$ & 2 & \\
\hline Negative Point of & It does not separate English from other courses. & 1 & 8 \\
\hline View & Does not respect the workload of English teachers. & 1 & \\
\hline & Does not take initiative for teaching English. & 1 & \\
\hline & It only implements the instructions from the Ministry. & 1 & \\
\hline No idea & No idea. & 1 & 1 \\
\hline
\end{tabular}

25 views were expressed under 6 sub-themes created within the context of the main theme of "positive perspective" for the question "School administrators' perspectives and approaches towards teaching English". These sub-themes were determined as follows: "has a positive impact", "caring, cares, cares and believes in its necessity", "supports effective English language teaching", "provides materials", "communicates with the Ministry of Education and provides the necessary learning environment", "doesn't cause any problems". The opinions of 5 teachers within the scope of these sub-themes are as follows:

"They approach it with care. They take the approach of teaching English effectively for children. They are ready to contribute to the development of English." (T1)

"There are generally positive attitudes and approaches towards English teachers." (T5)

"They are aware of the necessity and importance of our lesson." (S11)

"Although they themselves do not know much about English, I think that almost every manager is aware of the fact that the English language is important and necessary. Administrators have made an effort in their own way to meet my administrative demands for my field in general." (T12)

"They are involved and at the same time show due care and assistance." (T19)

Another main theme that emerged in the context of the question in question is the "negative perspective". For this main theme, 6 sub-themes and 8 opinions emerged. These sub-themes were determined as follows: "does not care", "does not understand English teaching and does not empathize with teachers", "does not distinguish English from other courses", "does not respect the workload of English teachers", "does not take initiative for teaching English", "only from the Ministry". executes instructions". 5 teacher opinions on these sub-themes are as follows:

"I've certainly never seen them give importance to foreign languages. I saw nothing but following the instructions from the ministry. I have never seen them take the initiative in anything." (T2)

"There is no different approach." (T8)

"Managers absolutely do not understand English teachers, they do not respect our workload." (S9)

"Insufficient..." (S16)

"They can't empathize." (T18)

The last main theme related to the question was put forward as "I have no idea" and 1 opinion was expressed about it: 
"I don't know the other side's opinions." (T10)

Table 9. Expectations of school administrators from english teachers

\begin{tabular}{ll}
\hline Theme & N \\
& \\
\hline Not expecting a different task from English teachers than other course teachers & 6 \\
Ensuring linguistic, cognitive and affective development in English teaching & 6 \\
Effective and comprehensive English teaching & 5 \\
Forcing the complete fulfillment of routine school duties & 4 \\
Requesting the harmonious working of the English department & 3 \\
Giving responsibilities beyond the primary duties of English teachers & 3 \\
Organizing events during the Languages week & 3 \\
Realizing a teaching in accordance with the English education program & 2 \\
\hline
\end{tabular}

32 views emerged under 8 themes for the question "Expectations of school administrators from English teachers". The identified themes are as follows: "Not expecting a different task from English teachers than other course teachers", "Providing linguistic, cognitive and affective development in English teaching", "Performing efficient and comprehensive English teaching", "Forcing the full fulfillment of the school's routine duties", " Asking for a harmonious work of the English department", "Assigning responsibilities other than the main duties of English teachers", "organizing activities during the language week", "Performing a teaching in accordance with the English education program".

In order not to expect a different task from English teachers, which was determined as the first theme, from other course teachers, a total of 6 English teacher opinions were put forward and 2 of them are given below:

"I have no different duties than other teachers." (T1)

"Unlike other teachers, there are no duties assigned to English teachers. Management expects similar responsibilities from all branches." (T6)

2 of the 6 views on the theme of "providing linguistic, cognitive and affective development in English teaching" are as follows:

"Because the English language is the core subject in colleges, it is emphasized that the English course should be made more comprehensive and the students should be at a certain level." (T3)

"They want to use school books and other materials effectively and to observe that students are using the language." (S11)

There were also 5 teachers' opinions for the theme of "Effective and comprehensive English teaching". Two of these views are as follows:

"It is my effective and active fulfillment of education and training tasks." (T19)

"They want us to impose language more heavily on children." (T23)

2 of the 4 opinions expressed for the theme of "forced fulfilling the routine duties of the school completely" for the question are given below:

"Since we test 4 skills as a branch, I expect them to be more understanding, especially in exam tasks and programs, but the situations have always been the opposite, they expect more than they expect from other branch teachers (example physical teachers) and give nothing in return." (S9)

"Extra assignments and exam scouts are given. Even though English teachers already have heavy duties brought by the branch..." (T10)

There are 3 teacher opinions for each of the themes of "wanting the English department to work in harmony", "giving responsibilities outside of the main duties of English teachers" and "organizing 
activities during the languages week". One teacher's opinion on these themes was presented as follows, respectively:

"The expectations of school administrators from English teachers are that they cover the same topics in accordance with the school curriculum and in communication with other English teachers at the same time." (T4)

"Different duties are assigned at the accident court, from being assigned as an interpreter to being an art director." (T14)

"The sole responsibility is to organize the annual English week." (T16)

Two opinions were expressed for the last theme of the question, "To carry out a teaching in accordance with the English education program", one of which is as follows:

"As an English teacher, they have an expectation of following the curriculum from the Ministry (This is a good thing). What is done is followed by keeping a group book." (T17)

Table 10. English teachers' expectations from school administrators

\begin{tabular}{ll}
\hline Theme & N \\
& \\
\hline Providing infrastructure and equipment in English teaching & 16 \\
The school administrator has positive personality traits and management skills. & 15 \\
Supporting English teachers and giving importance to foreign language teaching & 13 \\
English language classroom & 8 \\
Allowing the organization of extracurricular English activities & 6 \\
\hline
\end{tabular}

"Providing infrastructure and equipment in English teaching", "Positive personality traits and management skills of the school administrator", "Supporting English teachers and giving importance to foreign language teaching", "Establishing English language classrooms", "enabling the organization of extracurricular English activities" The themes are 5 themes related to the question "Expectations of English teachers from school administrators". 58 views on these themes were also presented.

16 opinions were expressed for the theme of "providing infrastructure and equipment in English teaching", 3 of which are given below:

"Renovating the foreign language room and making it suitable for today's technology, completing the lack of resources..." (S18)

"To ensure that the classrooms have the necessary technological equipment..." (S19)

"A more interesting language room could be made. Children can be supported to read/purchase English books. More source material can be provided." (T20)

Among the themes with the highest number of opinions, 3 teachers' opinions on "the school administrator's positive personality traits and management skills", which ranks second with 15 opinions, are as follows:

"It needs to be open to criticism." (T2)

"It needs to be fair, solution-oriented and open to new ideas." (T5)

"They need to be fairer, more transparent and accessible, and they need to empathize." (T10)

There are 13 teachers' opinions on the theme of "supporting English teachers and giving importance to foreign language teaching". Three of these opinions are given below:

"The awareness that English teachers have different loads than other teachers... For example, while a math teacher prepares a 2-page exam, as English teachers, we prepare and evaluate separate exams for speaking, listening, reading, writing, grammar and vocabulary skills." (T7) 
"I would like to not teach more than 15 hours because I want to be able to give credit to the four-skillbased language teaching whenever possible. Even assessment based on four skills takes weeks. When the production-based products accumulated throughout the semester are added to this, I would ideally like to attend classes for a maximum of -32 types and for a maximum of 15 hours in order to give the student the necessary feedback and to prepare properly for the lessons." (T12)

"There is an English club where we can demonstrate the use of English, organizing out-of-class activities, having an afternoon activity, and arranging the buses accordingly..." (S16)

8 opinions were expressed for the theme of "establishing an English language classroom", and 3 of them were presented as follows:

"Since we are a college, there should be a separate English room." (T1)

"Comfortable working environments and rooms should be created." (T8)

"Renovating the foreign language room and making it suitable for today's technology..." (S18)

There are 6 teachers' opinions on the last theme of the question, "to enable the organization of extracurricular English activities". Here are 3 views on this theme:

"To include plenty of English language activities (English poetry contest, quiz, etc.), to provide children with the opportunity to speak English with native English speakers (both with video and guest child system)..." (T4)

"Allocating a resource to give awards for the English lesson with the activities carried out..." (S11)

"Creating an environment that will allow more emphasis on educational games..." (T23)

After the opinions about the school administration, the opinions of English teachers about English lesson supervision and supervisors are presented in the tables below.

Table 11. Metaphors used by english teachers regarding the school administrator

Classification of Metaphors Related to the Concept of School Administrator as $f$

Concrete-Abstract and Alive-Inanimate

HUMAN: teacher, dictator, friend, parent, human

LIVE

ANIMAL: lion, octopus, sparrow

CONCRETE

PLANT: tree

LIFE number 1, egg, brand new, alarm clock, wood, energy 6 drink

When the metaphors of English teachers regarding this question were examined, it was seen that 18 opinions were expressed. It was revealed that 5 of the teachers did not express their opinions on the subject. It was observed that 18 of the teachers compared metaphors to a concrete entity, but it was 
found that there was no analogy to an abstract entity. Out of a total of 18 concrete metaphors, 12 are about living things and 6 are about inanimate objects. Of the concrete and living metaphors, 5 were expressed as human, 5 as animal and 2 as plant. Below are quotations from English teachers' metaphorical sentences:

Metaphors classified as concrete, living and human; teacher, dictator, friend, parent and human. The opinions of 2 teachers regarding these metaphors are as follows:

"It is like a teacher; because he has an attitude that understands us, who knows where he went. (at least for now)" (T1)

"Dictator; because it turns people against each other and cannot empathize." (T2)

Metaphors reflected as concrete, living and animal; lion, octopus and sparrow. The opinions of 2 teachers regarding these metaphors are as follows:

"It is like an octopus because it tries to catch up with everything" (T13)

"It's like a sparrow because it's naive and bleeds fast, it's sensitive." (T22)

The metaphor that is classified as concrete, living and plant is tree. The opinion of 1 teacher regarding this metaphor is as follows:

"It is like a tree because we form its branches, and the students form its fruits." (T7)

Finally, tangible and inanimate metaphors are number 1, egg, brand new, alarm clock, wood, energy drink. The opinions of 2 teachers regarding these metaphors are as follows:

"It is like the number 1... It increases in number by addition, keeps it constant with multiplication ... In other words, it is ready to help in case of demand, but does not make any extra contribution in other cases..." (T1)

"It is like wood because it is soulless." (T18)

If the reasons for the metaphors expressed by the teachers are evaluated, two classes can be formed as positive and negative. The positive ones are:

- Problem solving, helpful and trying to keep up

- Solid, strong and protective

- Evolving

- Knowing the past and knowing the teacher

- Sensitive and naive

- Energizing

Negative comments are as follows:

- Conflicting

- Only those who fulfill their responsibilities

- Not putting their emotions into their work

\section{Conclusion, Discussion and Recommendations}

In this section, the research findings are summarized and the results are written, followed by the discussion and suggestions sections. 
- When the positive opinions of English teachers about school administrators were evaluated, the personal characteristics of the administrator had the most important share in determining these opinions. Especially fair, egalitarian and honest and reliable administrators have been the points that the teachers focused on carefully. The number of teachers in school management are satisfied with the test if looked at, it seems to be less than half.

- The negative opinions of English teachers about school management are less than their positive opinions. This may be because they are more reserved in expressing negative opinions. Negative opinions are mostly that managers have problems with their management skills. Especially with regard to "conflict with teachers", English teachers stated that they had problems.

- On the issue of ideal school management, English teachers emphasized the importance of the school administrator and the teacher working in cooperation. In particular, it is expected that teachers will be recognized, their needs will be taken into account, ideas will be exchanged and arrangements will be made according to their branches.

- Two headings drew attention in the views of English teachers about what kind of school administrator they would like to work with. The first of these is related to the fact that the school administrator should have a personality trait that listens and can empathize. The other topic focuses on the necessity of the school administrator to be fair and egalitarian. Based on these two headings, it is seen that the personality traits of school administrators are at least as important as management skills and leadership.

- The feature that English teachers like the most in school administrators is that they are good at human relations and can communicate effectively. Based on this result, it was revealed that English teachers do not only expect to establish a formal relationship with school administrators and also attach importance to social relations.

- Among the features that English teachers do not like in school administrators they work with, there are rudeness, lack of understanding, lack of respect, discrimination and favoritism, inability to solve problems and being strict rules. Considering these negative features, it is seen that school administrators cause problems in different areas (such as organizational justice, organizational psychology, organizational climate).

- It is an important result of this research that school administrators have positive perspectives on teaching English. On the basis of this result, it was stated that English language teaching was valued and supported, materials were provided, and the necessary education and training environment was provided by communicating with the Ministry of Education.

- It has been revealed that school administrators do not expect different tasks from English teachers when compared to other course teachers. In addition, English teachers criticized the assignment of responsibilities other than their primary duties (translation).

- It was noteworthy that English language classrooms were built on the basis of the expectations of English teachers from school administrators. Based on this result, it was revealed that most of the TRNC secondary schools do not have English language classrooms.

- In the metaphors of English teachers about the school administrator, topics such as problem solving, protecting, making progress and getting to know the teacher show a positive perspective. On the other hand, negative opinions were determined as conflict, only fulfilling their responsibilities and not involving their emotions in the work.

\subsection{Discussion}


In this study, it was determined that the views of English teachers about school management were both positive and negative. In addition, some expectations of English teachers from school administrators were also revealed. In some previous studies, it can be seen that these situations take place. For example, in Demir's (2016) study examining the problems of English teachers that cause conflicts with school administrators during language education in Turkey, it was revealed that there are problems arising from school administrators. It was stated that the training processes of school administrators should be carefully examined and necessary changes should be made immediately. In this study, it has been revealed that the weaknesses of school administrators, especially arising from management skills, cause conflict with teachers. Mehdiyev (2019), in his research on English teachers' expectations from school management regarding teaching English, found that English teachers stated that language laboratories were missing in their schools and they wanted to give their lessons in language laboratories. In this study, a result that exactly overlaps with Mehdiyev's (2019) study was obtained. The expectations of English teachers in the TRNC to have a separate language class from school administrations were at the top of the list.

\subsection{Recommendations}

Depending on the results of the research, the following recommendations were developed by the researchers:

- English teachers expect school administrators to act by thinking about teachers and students while managing the school. Based on this result, it can be suggested that school administrators first determine the needs of teachers and students in school management and make planning.

- In order to improve the management skills of school administrators, it is necessary to develop a number of policies in the TRNC education system . In-service training on management training certificate, mentoring of experienced school administrators, conflict resolution, leadership and similar issues is required.

- It is important for school administrators to have effective meetings with teachers. In these meetings, it can be suggested to exchange ideas with the teacher and increase their decisionmaking situation together.

- Based on the conclusion that English teachers emphasized that school administrators should empathize, listen, be sensitive and understanding, it can be said that it would be important for school administrators to receive training on emotion management and to improve themselves.

- When we look at the characteristics that English teachers like in the school administrators they work with, it is seen that little emphasis is placed on supervising and strengthening the schoolfamily bond. For this reason, school administrators should pay attention to internal auditing and strengthening the school-family bond.

- Considering the disliked features of school administrators, it can be said that school administrators should acquire knowledge and skills in understanding teacher and student psychology.

- Based on the results of the research, some changes are needed in order to transform the negative perspective of school administrators towards teaching English into a positive one. For example, school administrators should be made more aware of the fact that teaching different language skills increases the workload of English teachers, the burden of assessment and evaluation increases and learning environments should be enriched with materials. In this 
context, the Ministry of Education, English inspectors and heads of schools at schools need to assume more active responsibility.

- Based on the expectations of English teachers, it can be suggested that school administrators know every field and school management should be carried out accordingly. For example, school administrators can be more active in organizing activities during the language week within the framework of teaching English.

- Within the scope of the expectations of English teachers from school administrators, the construction of English language classrooms can be accelerated by working in coordination with the Ministry of Education. In addition, it can be suggested that school administrators play an active role in matters such as providing equipment and organizing extracurricular activities in schools related to English teaching.

\section{References}

Başaran, I. E. (1994). Eğitim yönetimi. Ankara: Kadıoğlu Matbaası. https://www.kitantik.com/product/EGITIMYONETIMI 0z8kgltjhk5orch14gp

Bursalığlu, Z. (2019). Okul yönetiminde yeni yapı ve davranış. Ankara: Pegem. https://www.pegem.net/kitabevi/136-Okul-Yonetiminde-Yeni-Yapi-ve-Davranis--kitabi.aspx

Demir, E. (2016). Ingilizce öğretmenlerinin dil öğretiminde okul yöneticileri ile uyuşmazlıklarından kaynaklanan problemlerin incelenmesi üzerine bir araştırma, Yayımlanmamış Yüksek Lisans Tezi, Yeditepe Üniversitesi, istanbul.

https://tez.yok.gov.tr/UlusalTezMerkezi/tezDetay.jsp?id=dhNlehaEAtqADhHUnz7HFQ\&no=jsZFolS5EJmye 9EO2zLYzA

KKTC Milli Eğitim Bakanlı̆̆ı, (2005). Kıbrıs Türk Eğitim Sistemi, Lefkoşa: Talim Terbiye Dairesi Yayınları. http://talimterbiye.mebnet.net

KKTC Milli Eğitim Bakanlığı, (2014). V. Milli Eğitim Şura Kararları, Dil Eğitimi Komisyon Kararları, Gazi Mağusa. http://talimterbiye.mebnet.net

KKTC Milli Eğitim Bakanlığı, (2019). Vizyon 2030 Eğitim Stratejik Plan Çalıştayı Raporu, Lefkoşa: Talim Terbiye Dairesi Yayınları. http://talimterbiye.mebnet.net

Kumaravadivelu, B. (2003). Beyond methods: Macro strategies for language teaching. New Haven and London: Yale University Press. http://www.ugr.es/ isanz/archivos m3thodology/kumaravidelulibrocap1.pdf

Mehdiyev, E. (2019). English teachers' expectations and perceptions of support for English teaching. Bartın Üniversitesi Eğitim Fakültesi Dergisi, 8(3), 811-838. DOI: 10.14686/buefad.515656.

Özdoğancı, A. (2019). Öğretmenlerin pozitif okul yönetimine ilişkin görüşleri ile okula karşı tutumları arasındaki ilişki, Yayımlanmamış Yüksek Lisans Tezi, Pamukkale Üniversitesi, Denizli. http://acikerisim.pau.edu.tr:8080/xmlui/bitstream/handle/11499/26823/Av\%C5\%9Feg\%C3\%BCl\%20\%C3 \%96zdo\%C4\%9Fanc\%C4\%B1.pdf?sequence=1\&isAllowed =y

Şengül, M. (2020) . Anaokullarında karşılaşılan öncelikli yönetim sorunlarının okul yöneticilerinin görüşlerine göre incelenmesi, Yayımlanmamış Yüksek Lisans Tezi, Gaziantep Üniversitesi, Gaziantep. https://tez.yok.gov.tr/UlusalTezMerkezi/tezDetay.jsp?id=le08N4eJuybOYXKUnORDvQ\&no=IMHp263BRM 65UKDzYLRQ-Q

Şişman, M. Turan, S. (2005) Eğitim ve okul yönetimi. İçinde Eğitim ve okul yöneticiliği el kitabı, Ed. Y. Özden, ss. 99-146, Ankara: Pegem Yayıncllık. https://www.kitapyurdu.com/kitap/egitim-ve-okul-yoneticiligi-elkitabi/142554.html 
Guneyli, M. \& Kasot, N. (2021). The views of English teachers' towards school management and school managers. International Journal of Learning and Teaching. 13(3), 158-183. https://doi.org/10.18844/ijlt.v13i3.5971

Türkiye Ekonomi Politikaları Araştırma Vakfı (TEPAV), (2012). KKTC Milli Eğitim Bakanlığının Kurumsal ve Fonksiyonel Analizi, Ankara. https://www.tepav.org.tr/upload/files/14550086576.KKTC Milli Egitim Genclik ve Spor Bakanligi Kurumsal ve Fonksiyonel Analizi.pdf

Ünal, S. ve Ada, S. (1999). Öğretmenlik mesleğine giriş. İstanbul: Marmara Üniversitesi Yayınları. https://www.nadirkitap.com/ogretmenlik-meslegine-giris-semra-unal-sefer-ada-kitap8176553.html

Yıldııım, A. ve Şimşek, H. (2021). Sosyal bilimlerde nitel araştırma yöntemleri, 12. Baskı, Ankara: Seçkin Yayınevi. https://www.seckin.com.tr/kitap/176755156\# 